\title{
Indigenous Media and Rural Development: The Case of Oil Producing Communities in Akwa Ibom State, Nigeria
}

\author{
Coleman F. Essien, Federal University of Technology, Nigeria
}

\begin{abstract}
This study is an attempt to provide lucid and perhaps comprehensive information on the role of traditional media on rural development in four oil producing communities in Akwa Ibom State, Nigeria. It identifies types of traditional communication channels available for rural development, it examines the effectiveness of these channels of communication, and establishes how messages are packaged and presented in performance. The study employed descriptive survey design. The population of the study comprised 200 respondents sampled from the four communities. Simple random sampling technique was used to select 50 out of 200 respondents that constituted the sample for this study each from the four communitiesin Ikot Abasi Local Government, Akwa Ibom State. The result of the study among others showed that indigenous media are still being effectively used on rural development. Apparently vast majority of respondents strongly agreed that indigenous media are effective in disseminating information on rural development. The findings also showed that indigenous media facilitates communication among the rural people on community development. The study among others recommended that the government through the ministry of information and culture should improve the role of folk mediaby organizing regular workshops and seminar for the training of stakeholders in media operations.
\end{abstract}

Keywords: Indigenous Media, Rural Development, Oil Producing communities. 


\section{Introduction}

The role of traditional folk media has been very significant in rural development since the turn of this century, and with the advent of new media, the forms and ways of communication have become more specialized. Every human society has developed its traditional modes and channels of communication which characterize its existence, organization and development. These communication modes and channels form the basis upon which the communities, especially the rural community, progress (Orewere 1991).Communication, that is, transmission of information from a point called origin or source to another called destination or receiver (audience), is the life wire of every society. No wonder people continue to marvel at the continued relevance of the African indigenous media; otherwise, known as African traditional folk media, in the contemporary world despite the manifestation of Marshall McLuhan's theory of 'Global Village' in the contemporary world. The first significant recognition of the traditional media in the communication and development strategies of the developing countries came in the year 1972 when the international parenthood federation and UNESCO organized a series of meetings in London relating to integrated use of traditional folk media in family planning communication programmes. The interest generated by this meeting and the continued efforts to highlight the folk media as effective form of conveying developmental messages resulted in a number of seminars and workshops around the world (Mohanty \& Parhi, 2011). UNESCO, (1999),also organized a seminar to provide a forum for the discussion and formulation of strategies for promoting and enhancing the development of traditional media in African countries. The importance of the seminar resided in the priority given by UNESCO, in its communication strategy and programmes in Africa, to encourage and support the development of folk media which helps to expand access to news and information and provide more opportunities for communities to express themselves.

Nigeria is characterized by a complex social system with different classes and ethnic groups with $80 \%$ of her population residing in the rural areas; hence, the need for sustainable rural development (Akpoveta, 2006). Traditional community communication in Nigeria has a unique network which may not be easily understood. It is difficult to understand this network through externally imposed philosophies and concepts. To appreciate this network, one has to live in the 
village, observe, studyand understandit. This communication network can be effectively used for rural development (Orewere, 1991). The reason for the popularity and effectiveness of this mode of communication for development-oriented messages is that it is transactional and highly participatory, allowing participants to work with new information through a familiar and comfortable format (Ansu-Kyeremeh, 1998).

To the rural people, the mass media proved only to be glamorous, impersonal and unbelievable in comparison with the familiar performance of traditional artist whom the villagers could see and hear and even touch emotionally. Obviously, the traditional media is the right choice of media to carry messages to the rural community for the purpose, and process of change and development (Stichele, 2000). It is also viewed that dialogue is the essence of any work in communication for development. As a matter of fact, traditional media have a remarkable impact on rural areas because of their acceptable idioms, functional significance and entertainment component. It can overcome language difficulty, speech, words and other barriers of communication like interest, understanding, interpretation, attitude and perception. Folk media are the most important vehicle of social change. It is used for educational purposes and as a tool to reform society. It helps to convey educational messages through entertainment, costume, music, dance etc.

Traditional media have always played a major role in rural development; for example in precolonial days, people carved stories on stones and temples and as a result, today we have known a lot about early cultural development by seeing the sculptures and rock paintings of such stories. Subsequently, with the invention of print and electronic media, it made easier for people to know about the happenings around the world through newspapers, radio, television, internet etc. Traditional media are based on indigenous culture, produced and consumed by members of rural communities. (Adoyo 2004) noted that many rural people utilize folk media for communication of culture messages. In African context, sensitive information is never passed in a straightforward manner but through songs, dances, drum, town crier and plays using proverbs and poems. The town crier is a source of news and information. He is a major social and cultural 
facilitator helping to form attitudes, values and develop a climate of change. However, the reality of town crier is that he serves only rural areas and largely the illiterate populace.

Oral societies do generate and utilize a vast amount of information on development embodied in such societies' oral tradition (Fayose, 1980). Oral tradition is embedded in folk media and is an important communication vehicle for promoting and improving dialogue which the common people or the rural farmers employ to deliver their messages (Zwaal, 2000). Traditional folk media have remained a significant tool in the process of motivating people in the desired direction. It is a means of development and educational communication as well as the most appropriate medium for bringing about changes in attitudes as it is informal and unscripted in nature. This in turn helps the rural masses to accept social changes. For example, the use of traditional media can help to create awareness about the need for cleanliness in the neighbourhood.

\section{Statement of the Problem}

In Nigeria and indeed other third world countries, greater percentage of the people still live in rural areas. It is perhaps for this reason that it is now being advocated that in such countries, particular attention must be paid to the rural areas in any development strategy if there is to be any noticeable general national development. Traditional folk media which should provide an effective tool for dealing with development problems in rural areas has not been properly articulated in the mainstream development process. Hence attempts at communicating modern scientific and technological information to the rural people on rural development often result in the failure of such projects.

Rural development is a broad term and certain aspects like health, education, employment generation, infrastructure, environment protection, sanitation, energy conservation and entertainment can be the determinants of rural development. Judging from the failure of many rural development efforts to produce the desired effects, it is clear that there are defects in the communication processes embodied in those efforts especially when modern media, instead of traditional folk media is introduced into the rural development process. The characteristics of the 
sources, messages, channels, recipients and feedback involved in the process of communicating with rural communities need to be examined to see how they can be made more appropriate. A careful examination of rural areas will show that rural people are exposed to quite a lot of information, but the problem, however, is whether the information reaching them is reliable and organized in such a way as to achieve defined objectives.

It is also clear that not all the information required for rural development is available or accessible to the rural dwellers. The problem of this study therefore, is to find out how to facilitate access to this information by rural people for the purpose of development.

\section{Objectives of the Study}

The objective of this study is to look at the roles of indigenous folk media in the development of four oil producing communities in Ikot Abasi Local Government Area, Akwa Ibom State, Nigeria, its contribution and success in the implementation of development projects.

Specifically, the objectives of this study are to:

1) Examine the role of indigenous folk media in rural development in three oil communities;

2) Identify types of traditional communication channels available for rural development;

3) Examine the effectiveness of these channels of communication;

4) Establish how messages are packaged and presented in performance;

\section{Significance of Study}

(i) The study will preserve the originality of each folk media form for rural dwellers

(ii) It will generate a number of guiding principles for the government and development agencies on how to use folk media for motivational purpose and for promoting rural development programmes.

(ii) The rural dwellers will rediscover the potential of performing indigenous arts in their domain as a weapon in their struggle for good health status, enhanced working and living conditions, political and human rights etc.

(iii) Development planners will begin to appreciate the use of folk media as a mode of communication to explain development programme. 


\section{Research Questions}

RQ1 What are the roles of indigenous folk media in rural development?

RQ2 What are the types of traditional communication channel available for rural development?

RQ3 How effective are these channels of communication?

RQ4 How are messages packaged and presented in performance?

\section{Literature Review}

Writing on the forms and channels of indigenous folk media, Paul Mundy and J. Lin Compton (1991) state that the media are the indigenous equivalents of mass media. They are used primarily for entertainment, but also to promote education, values and cultural continuity. They include festivals, plays and puppet shows, dance, song, story-telling, poetry, and debates. Many have been adapted to transmit messages about family planning, politics and other exogenous topics. They went further to list indigenous organizations which include religious groups, village meetings, irrigation associations, mothers' clubs and loan associations. Apart from the formal communication they permit, such organizations provide many opportunities for informal interaction.Moemeka (1981)made an interesting discovery on media influence on development project. His findings of a survey to determine which of media (traditional and modern) the rural population of former Bendel State depended upon on their response to three development projects showed clearly the superiority of traditional media. The findings indicate that such traditional modes as social forums, town crier and local market proved to be more effective than radio, newspaper and television in rural development effort. He further stated that an endorsement by a traditional ruler can make the difference between getting political office and losing out completely, as many politicians have since learnt their lesson.

Ansu-kyeremeh (1998) is of the opinion that the marginalization of traditional media in the past by the colonialist was a calculated attempt to discredit the system. He stressed that Eurocentric claims that traditional values and lifestyles are wrong and outmoded was not true. He said that the fact remains that traditional communication has continued to flourish in the rural areas. Political campaign in rural communities especially in Nigeria is anchored on traditional media 
and in the same vein dissemination of development messages without factoring in these indigenous communication modes will be an exercise in futility. However,it is quite interesting to note that after many years of the exit of colonialism, indigenous media is still not striving in the rural area hence Akpomuvie (2010) examines the imbalances in the living conditions of the urban and rural dwellers. He asserted that the odds against rural development in Nigeria were rather immense and alarming. He stressed that the configurations of government plans were tailored strictly to facilitate the exploitation of the natural resources of the rural areas for the development of the few urban centres. Consequently, most of the initial infrastructural developments in Nigeria were skewed in favour of the urban areas to the detriment of the rural areas where the majority resided and inadvertently created a dualism. Since the government was "far" from the rural areas in terms of development and with the realization that government alone cannot provide all their needs, the people had to learn to "do-it-themselves". This alternative strategy of self-help and the communitarian philosophy of the people have not only accelerated the level of growth but have also spread the benefits of development to the rural areas in Nigeria. However, where the government is properly playing its expected role, self-help activities should complement rural development and not replacing it.

According to UNESCO report (1999) on promoting rural media in Africa, it was observed that the lack of political support for community media, coupled with media privatization and commercialization had resulted in communities being marginalized. Those with political and economic power benefited from media liberalization, and community media lack the economic, technical and human resources needed to sustain them. The report stressed that communities should have the means to articulate their needs and control their own messages. It was proposed that the media and rural communities should create a synergy to find effective solutions to development needs. Emphasis was also laid on the formulation of strategies for promoting and enhancing the development of rural community media in African countries.It was also stressed that people were not mere recipients of information and that, with the policy of decentralization; both modern and traditional participatory communication methods could be developed to meet the needs of different social groups, particularly the disadvantaged and marginalized. The report called for ethnographic communication research and needs assessment as necessary stages in developing community media. 
Community media should involve community members in determining the kind of communication technologies which are appropriate to use and that such technologies should be compatible with the environment and respond to the needs of the community. Those community media practitioners integrate traditional media that exist in the communities with modern media to ensure an effective media mix in the dissemination of news and information. In his contribution, Akpabio (2000) contends that modern mass media and traditional folk media can work together to bring the desired goal of rural development to a success. He said that with the combination of the two systems, what each cannot achieve single handedly, becomes achievable with increased knowledge and attitude change. This still goes to underline the importance of indigenous communication forms in rural development as observed by Tiemtore on the effect of local radio as a tool for rural development in Burkina Faso. He said that traditional folk media remained relevant even with the level of technological leap of its modern counterpart.

\section{Research Methods}

The survey research method was adopted for this study with questionnaire as the main instrument. 100 respondents were chosen each from Ukan, and Ibekwe, while 100 respondents were picked from Essene and Ette, in Ikot Abasi Local Government Area, representing the four oil communities using the purposive sampling technique. The total of 200 respondents constituted the sample for this study. The population of the sample comprises of male and female with age range between 18 and 75 years. The sample size was restricted to 200 to enable the researcher do a thorough work.Simple random sampling method was used to generate data in this study whilethe research sample for the study was randomly selected from the four communities. 


\section{Results and Analysis}

RQ1: What are the roles of traditional folk media in rural development?

\begin{tabular}{|c|c|c|c|c|}
\hline $\mathrm{S} / \mathrm{N}$ & Category & Decision Level & Frequency & Percentage \\
\hline 1. & $\begin{array}{l}\text { Traditional media is effective in } \\
\text { disseminating information on rural } \\
\text { development }\end{array}$ & $\begin{array}{l}\text { Strongly Agree } \\
\text { Agree } \\
\text { Disagree } \\
\text { Strongly Disagree }\end{array}$ & $\begin{array}{c}128 \\
59 \\
6 \\
7\end{array}$ & $\begin{array}{c}64.0 \% \\
29.5 \% \\
3.0 \% \\
3.5 \%\end{array}$ \\
\hline & & Total & 200 & $100 \%$ \\
\hline 2. & $\begin{array}{l}\text { Traditional media facilitates } \\
\text { communicating among the rural people on } \\
\text { community development }\end{array}$ & $\begin{array}{l}\text { Strongly Agree } \\
\text { Agree } \\
\text { Disagree } \\
\text { Strongly Disagree }\end{array}$ & $\begin{array}{l}84 \\
58 \\
27 \\
31\end{array}$ & $\begin{array}{l}42.0 \% \\
29.0 \% \\
13.5 \% \\
15.5 \%\end{array}$ \\
\hline & & Total & 200 & $100 \%$ \\
\hline 3. & $\begin{array}{l}\text { Traditional media supports/complements } \\
\text { the government and development agencies }\end{array}$ & $\begin{array}{l}\text { Strongly Agree } \\
\text { Agree } \\
\text { Disagree } \\
\text { Strongly Disagree }\end{array}$ & $\begin{array}{l}24 \\
32 \\
96 \\
48\end{array}$ & $\begin{array}{l}12.0 \% \\
16.0 \% \\
48.0 \% \\
24.0 \%\end{array}$ \\
\hline & & Total & 200 & $100 \%$ \\
\hline 4. & $\begin{array}{l}\text { Traditional media is used as a mode of } \\
\text { communication to explain development } \\
\text { programmes to the rural people }\end{array}$ & $\begin{array}{l}\text { Strongly Agree } \\
\text { Agree } \\
\text { Disagree } \\
\text { Strongly Disagree }\end{array}$ & $\begin{array}{l}68 \\
76 \\
22 \\
34\end{array}$ & $\begin{array}{l}34.0 \% \\
38.0 \% \\
11.0 \% \\
17.0 \%\end{array}$ \\
\hline & & Total & 200 & $100 \%$ \\
\hline
\end{tabular}

The presentation and data analysis of this work is based on the questionnaire instrument to investigate the roles of traditional media on rural development. Apparently from the questions, the data presented above revealed that 128 (64\%) of the respondents strongly agreed while 59 (29.5\%) agreed that traditional media are effective in disseminating information on rural development. On the other hand, $6(3 \%)$ and 7 (3.5\%) of the respondents disagreed and strongly disagreed respectively on the above subject. This result might be attributed to the fact that through the process of acculturation, the rural people gradually diluted their mind in appreciating the core value of the traditional media. Item 2 was an attempt to find out if traditional media facilitates communication among the rural people on community development. The table showed that $84(42 \%)$ of the respondents strongly agreed, while $58(29 \%)$ agreed that traditional media facilitates communication among rural people. The number of respondents who disagreed and strongly disagreed were $31(15.5 \%)$ and $27(13.5 \%)$ respectively. 
Item 3 reveals that vast majority of respondents 24 (12\%) strongly agreed and 32 (16\%) agreed that traditional media supports/complements government and development agencies in rural development. However, 96 (48\%) disagreed and 48 (24\%) strongly disagreed in their opinions as shown in table. It shows a drastic decline in respondents' opinion on traditional media supports/complements government and development agencies in rural development. The table also showed that $68(34 \%)$ and $76(38 \%)$ respondents strongly agreed and agreed while only 34 $(17 \%)$ and $22(11 \%)$ disagreed and strongly disagreed that traditional media are used as a mode of communication to explain development programme to the rural people. Therefore the table shows that low percentage of respondents supported the fact that traditional media supports/complements government and development agencies.

However, item 1 to 3 shows that majority strongly believed that traditional media are used as a mode of communication. This is evident in the growing number of government projects in the three communities under study.

\section{RQ 2: What are the types of traditional communication channel available for rural} development?

\begin{tabular}{|l|l|l|c|c|}
\hline S/N & Category & Decision Level & Frequency & Percentage \\
\hline 5. & Messages are communicated through & Strongly Agree & 101 & $50.5 \%$ \\
& beating of special drum & Agree & 32 & $36.0 \%$ \\
& & Disagree & 7 & $3.5 \%$ \\
& & Strongly Disagree & 20 & $10.0 \%$ \\
\hline 6. & Messages are communicated through & Total & 200 & $100 \%$ \\
& Songs (dance, work songs) & Agree & 87 & $43.5 \%$ \\
& & Disagree & 74 & $37.0 \%$ \\
& & Strongly Disagree & 18 & $9.0 \%$ \\
\hline 7. & Messages are communicated through & Strongly Agree & 21 & $10.5 \%$ \\
& village crier otherwise known as town & Agree & 91 & $100 \%$ \\
& crier & Disagree & 42 & $36.0 \%$ \\
& & Strongly Disagree & 23 & $7.0 \%$ \\
\hline & Messages are communicated through & Strongly Agree & $84.5 \%$ \\
\hline 8. & folk tales, proverbs and riddles & Agree & 71 & 14 \\
& & Disagree & 21 & $10.5 \%$ \\
& & Strongly Disagree & 24 & $12.0 \%$ \\
\hline & & Total & 200 & $100 \%$ \\
\hline
\end{tabular}


As revealed in above table, beating of special drum is considered as the most popular medium for communicating messages for rural development. In item 5, 101 (50.5\%) strongly agreed while $72(36 \%)$ agreed that messages are communicated through beating of special drum. Meanwhile, 7 (3.5\%) disagreed and 21 (10.5\%) strongly disagreed and respectively on the same subject. The analysis made on the basis of data presented in item 6 reveals that about 87 (43.5\%) and $74(37 \%)$ of the respondents strongly agreed and agree that messages are communicated through songs (dance, work songs). However, 18 (9\%) disagreed and 21 (10.5\%) of the respondents strongly disagreed respectively. The overall result is that the number of respondents who strongly agreed was higher than the rest.

The relative efficiency of traditional communication channels can be determined by how frequently the media are used for the types of audience and the place at which the media are used. These are the determining factors that speak about the efficiency of media used in message dissemination. In item 7, the respondents 91 (45.5\%) strongly agreed while 72 (36\%) agreed that messages are communicated through village crier. Meanwhile, 14 (7\%) disagreed and 23 $(11.5 \%)$ strongly disagreed that village crier communicates messages on rural development. On whether beating of special drum is still effective means of communicating messages, item 8 shows that $24(12 \%)$ of the respondents strongly agreed, while $21(10.5 \%)$ agreed that messages are communicated through folk tales, proverbs and fiddles. It was also revealed that through this media, important information is passed from generation to generation. Meanwhile, 71 (35.5\%) and $84(42 \%)$ disagreed and strongly disagreed on the same subject.

\section{RQ 3: How effective are these channels of communication?}

\begin{tabular}{|l|l|l|c|c|}
\hline S/N & Category & Decision Level & $\begin{array}{c}\text { Frequenc } \\
\mathrm{y}\end{array}$ & Percentage \\
\hline 9. & Beating of special drum is still effective & Strongly Agree & 99 & $49.5 \%$ \\
& means of communicating messages on & Agree & 80 & $40.0 \%$ \\
& rural development & Disagree & 3 & $1.5 \%$ \\
& & Strongly & 18 & $9.0 \%$ \\
\hline & Disagree & & \\
\hline
\end{tabular}




\begin{tabular}{|c|c|c|c|c|}
\hline \multirow[t]{2}{*}{10.} & $\begin{array}{l}\text { The function of town crier in } \\
\text { dissemination information is still in use } \\
\text { in rural development programmes }\end{array}$ & $\begin{array}{l}\text { Strongly Agree } \\
\text { Agree } \\
\text { Disagree } \\
\text { Strong Disagree }\end{array}$ & $\begin{array}{l}93 \\
80 \\
10 \\
17\end{array}$ & $\begin{array}{c}46.5 \% \\
40.0 \% \\
5.0 \% \\
8.5 \%\end{array}$ \\
\hline & & Total & 200 & $100 \%$ \\
\hline 11. & $\begin{array}{l}\text { Songs (dance, work songs) constitutes } \\
\text { effective means of communication in } \\
\text { rural development }\end{array}$ & $\begin{array}{l}\text { Strongly Agree } \\
\text { Agree } \\
\text { Disagree } \\
\text { Strongly } \\
\text { Disagree }\end{array}$ & $\begin{array}{l}80 \\
77 \\
21 \\
22\end{array}$ & $\begin{array}{l}40.0 \% \\
38.5 \% \\
10.5 \% \\
11.0 \%\end{array}$ \\
\hline & & Total & 200 & $100 \%$ \\
\hline 12. & $\begin{array}{l}\text { Functions of folktales, proverbs and } \\
\text { riddles cannot be underestimated as a } \\
\text { tool for rural development }\end{array}$ & $\begin{array}{l}\text { Strongly Agree } \\
\text { Agree } \\
\text { Disagree } \\
\text { Strongly } \\
\text { Disagree } \\
\end{array}$ & $\begin{array}{l}76 \\
72 \\
30 \\
22\end{array}$ & $\begin{array}{l}38.0 \% \\
36.0 \% \\
15.0 \% \\
11.0 \%\end{array}$ \\
\hline & & Total & 200 & $100 \%$ \\
\hline
\end{tabular}

It is observed from item 9 that about 99 (49.5\%) of the respondents strongly agreed that beating of special drum is still effective means of communicating messages on rural development while $80(40 \%)$ agreed on the same subject. On the other hand, $3(1.5 \%)$ disagreed and $18(9 \%)$ strongly disagreed respectively. Similarly, next item shows that $80(40 \%)$ and $93(46.5 \%)$ of the respondents disagreed and strongly disagreed that function of village crier in disseminating information is still in use in rural development programmes. Also 10 (5\%) and $17(8.5 \%)$ disagreed and strongly disagreed that village crier is still performing it functions today. The importance of town crier cannot be overemphasized in rural development programmes.

In item 11, $80(40 \%)$ of the respondents strongly agreed while $77(38.5 \%)$ agreed that songs (dance, work songs) constitutes effective means of communication on rural development. Meanwhile, 21 (10.5\%) and 22 (11\%) disagreed and strongly disagreed respectively on the same subject. However, overall impression is that greater percentage of respondents strongly agreed that songs (dance, work songs) constitutes effective medium of communication on rural development. Information obtained in item 12 established the fact that the functions of folktales, proverbs and riddles is diminishing. As can be seen in item 12, 22 (11\%) respondents strongly agreed while $30(15 \%)$ agreed respectively. On the contrary, $72(36 \%)$ and $76(38 \%)$ respondents disagreed and strongly disagreed on the same issue. There is a decline in item 12 
which is an indication of low level patronage of this channel of communicationas a tool for rural development.

RQ 4: How messages are packaged and presented in performance?

\begin{tabular}{|c|c|c|c|c|}
\hline $\mathrm{S} / \mathrm{N}$ & Category & Decision Level & Frequency & Percentage \\
\hline 13. & $\begin{array}{l}\text { Composition of songs, dances and } \\
\text { special speeches that grace ceremonies } \\
\text { carry messages }\end{array}$ & $\begin{array}{l}\text { Strongly Agree } \\
\text { Agree } \\
\text { Disagree } \\
\text { Strongly Disagree }\end{array}$ & $\begin{array}{l}77 \\
86 \\
16 \\
21\end{array}$ & $\begin{array}{c}38.5 \% \\
43.0 \% \\
8.0 \% \\
10.5 \%\end{array}$ \\
\hline & & Total & 200 & $100 \%$ \\
\hline 14. & $\begin{array}{l}\text { Messages are packaged by devising the } \\
\text { most effective medium at initiation, } \\
\text { funeral or at a wedding ceremonies }\end{array}$ & $\begin{array}{l}\text { Strongly Agree } \\
\text { Agree } \\
\text { Disagree } \\
\text { Strongly Disagree }\end{array}$ & $\begin{array}{l}67 \\
67 \\
43 \\
23\end{array}$ & $\begin{array}{l}33.5 \% \\
33.5 \% \\
21.5 \% \\
11.5 \%\end{array}$ \\
\hline & & Total & 200 & $100 \%$ \\
\hline 15. & $\begin{array}{l}\text { Symbols and images are used that make } \\
\text { sense to the folk on rural development }\end{array}$ & $\begin{array}{l}\text { Strongly Agree } \\
\text { Agree } \\
\text { Disagree } \\
\text { Strongly Disagree }\end{array}$ & $\begin{array}{l}67 \\
53 \\
49 \\
31\end{array}$ & $\begin{array}{l}33.5 \% \\
26.5 \% \\
24.5 \% \\
15.5 \%\end{array}$ \\
\hline & & Total & 200 & $100 \%$ \\
\hline 16. & $\begin{array}{l}\text { Local trees, animals, landscape and } \\
\text { weather play a major part in the way } \\
\text { messages are coded and delivered }\end{array}$ & $\begin{array}{l}\text { Strongly Agree } \\
\text { Agree } \\
\text { Disagree } \\
\text { Strongly Disagree }\end{array}$ & $\begin{array}{l}40 \\
50 \\
55 \\
55\end{array}$ & $\begin{array}{c}20 \% \\
25 \% \\
27.5 \% \\
27.5 \%\end{array}$ \\
\hline & & Total & 200 & $100 \%$ \\
\hline
\end{tabular}

Songs, dances and special speeches that grace ceremonies is a popular performance in Ikot Abasi local government area. This aspect of traditional media is said to have been originated many centuries ago in many communities in the local government. The dance and songs may be staged for several hours and within that time, the mythological stories is fully narrated by the players that may be very effective in communicating development programme to the rural people. In item 13, $77(38.5 \%)$ of the respondents strongly agreed while $86(43 \%)$ agreed that composition of songs, dances and special speeches that grace ceremonies like weddings, burial, coronation etc. carry messages. However, $16(8 \%)$ and $21(10.5 \%)$ of the respondents disagreed and strongly disagreed on the above subject matter. In overall, higher percentage of the respondents strongly agreed that songs, dances and speeches carry message that could enhance rural development. 
Item 14 indicates that $67(33.5 \%)$ of the respondent, in their opinion strongly agreed that messages are packaged by devising the most effective means at initiation, funeral or at a wedding ceremonies. Also 67 (33.5\%) agreed on the same subject matter. Meanwhile 43 (21.5\%) and 23 $(11.5 \%)$ both disagreed and strongly disagreed respectively. However, looking at the overall table, it is clear that higher percentage of respondents believed that messages are packaged by devising the most effective mean at initiation, funeral or at a wedding ceremonies.

The role of symbols and images in traditional media is very important because before the advent of writing, symbols and images were the only sources of communication in socio-economic sphere. Therefore in rural development efforts, symbols and images play significant roles. The data displayed in item 15 shows that 67 (33.5\%) and $53(26.5 \%)$ of the respondents strongly agreed and agreed respectively. Meanwhile 49 (24.5\%) and 31 (15.5\%) disagreed and strongly disagreed that symbols and images are used that make sense to the folk on rural development.Item 16 carries information on the way and manner local trees, animals, landscape and weather play a major part in the way messages are coded and delivered. 40 (20\%) of the respondents strongly agreed while 50 (25\%) agreed on the same subject. Meanwhile, 55 (27.5\%) and $55(27.5 \%)$ of the respondents disagreed and strong disagreed respectively. In all, those who strongly agreed that local trees, animals, landscape and weather play a major part in the way messages are coded and delivered were higher than others. Today local trees, animals, landscape etc. are still in use for development purposes.

\section{Conclusion}

This research study examined the role of indigenous media on rural development of four oil producing communities in Akwa Ibom State, Nigeria. Based on the findings of the study, the following conclusions were drawn;An overview of the overall results of the study showed a high inclination of the application of traditional media on rural development. In other words, the role of indigenous media on rural development has been successful in project implementation in the three oil producing communities as seen in the responses. The result shows that majority of the respondents strongly agreed that indigenous media are effective in planning and execution of development projects. It was also observed that all facets of traditional media enhances rural 
development except that emphasis on the use of local trees, animals, landscape and weather as a way of coding and delivery of messages have tremendously reduced due to environmental factor such as deforestation, excessive land use, bush burning and hunting activities in the area.

Finally, it was also found that the role of traditional folk media on rural development is still viable, that traditional channels of communication such as drums, songs, village crier and folktales are still effective way of communicating development programmes. Messages are packaged and presented in performance. This is exemplified by different project initiated by the state and local governments. The communication potentials of indigenous media have been proven time and again in the history of development in various communities.

\section{Recommendations}

From the findings of the study, the following recommendations are made:

1) The government through the ministry of information and culture should improve the role of indigenous folk media by organizing regular workshops and seminar for the training of stakeholders in indigenous media operations.

2) A number of guiding principles should be generated by the government on how to use indigenous media for motivational purposes and promoting development programmes.

3) Not all folk forms can be used for development communication purposes; thus they should be carefully studied from the point of view of content and characterization for the possible adaptation for development purpose.

4) Indigenous media productions should be consistent with the needs of the social context and related to the customs and belief of the local communities.

5) Traditional media makes communication among the rural people more effective and authentic when employed for development activities of the society, therefore, the government should encourage the development of traditional communications in all it ramification. 


\section{References}

Adoyo, F. (2004). The mirror technique in rural extension. Ileia, April, 28, pp. 1-4.

Akpabio, E. (2000). Communicating AIDS to the rural populace A paper presented at the $2^{\text {nd }}$ National Conference of the School of Arts and Social Sciences, Tai Solarin College Education Ijebu Ode from December 4-7, 2000.

Akpomuvie, O. B. (2010). Self-Help as a strategy for Rural Development in Nigeria: A BottomUp Approach. Journal of Alternative Perspectives in the Social Science 2 (1), 88-111.

Akpoveta, E. (2006). Communication as a tool for sustainable rural development. International Journal of Communication 4:205-216.

Ansu-Kyeremeh, K. (1998). Perspectives on indigenous communication in Africa. Ghana: University of Ghana Printing Press.

Mohanty M. and Parhi P. (2011). Folk and traditional media: A powerful tool for rural development. Journal of Communication, Vol. 2(1) 41-47.

Fayose, P.O. (1990).Information management and dissemination in orally literate societies. Ibadan: Wisdom Publishers.

UNESCO, (1999). Regional Seminar on Promoting Community Media in Africa: Synthesis, proceedings and recommendations. Kampala, Uganda.

Orewere, B. (1991). Possible implications of modern mass media for traditional communication in a Nigeria rural setting. African Media Review Vol. 5 (3) 1991.

Paul M. \& Compton L.J. (1991). Development communication report 74, 1991/3. Clearinghouse on Development Communication, Arlington, VA.

Stichele, P.V. (2000). Folk and traditional media for rural development" Retrived January 12, from www.fao.org/sd/KDdirect/CDre0052.htm

Zwaal, P.N. (2004). Story telling as a vehicle for improving inter-cultural dialogue. Thesis on environmental conservation in Cameroon. (Retrieved May 30, 2005). 